\title{
Biological Distribution and Physiological Role of the $\beta$-Ketoadipate Transport System
}

\author{
By JOANNE M. ONDRAKO AND L. NICHOLAS ORNSTON* \\ Department of Biology, Yale University, New Haven, Connecticut 06520, U.S.A.
}

(Received 19 February 1980)

\begin{abstract}
$\beta$-Ketoadipate induces catabolic enzymes in Pseudomonas putida. The compound is transported by a system which also concentrates adipate, a non-metabolizable analogue of $\beta$-ketoadipate. The natural substrate, $\beta$-ketoadipate, competitively inhibits adipate transport with a $K_{\mathrm{i}}$ of $0.04 \mathrm{mM}$, lower than the $K_{\mathrm{m}}$ of $0.23 \mathrm{~mm}$ observed with adipate. Transport is inhibited competitively by succinate $\left(K_{1} 1.3 \mathrm{~mm}\right)$ and non-competitively by acetate $\left(K_{1} 5.3 \mathrm{~mm}\right)$. The system has a sharp $\mathrm{pH}$ optimum at 5.5 . Transport activity is stimulated by a variety of ions, and salt concentrations in excess of $0.1 \mathrm{M}$ are required to achieve optimal rates of influx. The transport system is inhibited by proton conductors and thiol reagents. Membrane vesicle preparations concentrate adipate when supplied with an oxidizable energy source. Induction of the transport system does not allow the rapid utilization of exogenous $\beta$-ketoadipate. Nevertheless, the system has been conserved in the evolution of divergent Pseudomonas species. The selective value of the $\beta$-ketoadipate transport system may lie in its apparent function in chemotaxis and in its ability to control intracellular concentrations of the inducing metabolite, $\beta$-ketoadipate.
\end{abstract}

\section{INTRODUCTION}

$\beta$-Ketoadipate is a regulatory metabolite in fluorescent pseudomonads (Ornston \& Parke, 1977), and it induces the co-ordinate synthesis of three catabolic enzymes that give rise to it during the dissimilation of protocatechuate (Fig. 1). In Pseudomonas putida strain PRS2000, the enzymes share a regulatory gene with a transport system that acts on adipate, a chemical analogue of $\beta$-ketoadipate (Ornston \& Parke, 1976). The regulatory gene lies near the structural gene for the enzymes (Thayer \& Wheelis, 1976), and mutations in the regulatory gene lead to the constitutive production of both the enzymes and the transport system (Parke \& Ornston, 1976). The biological distribution of the transport system has not been explored hitherto, but continuing pressure for its selection would lead to its evolutionary conservation in pseudomonads that share the induction pattern of $P$. putida (Ornston, 1971).

The transport system possesses several anomalous properties. Its biosynthetic regulation appears to be relatively lax: it is induced in wild-type $\boldsymbol{P}$. putida cultures only a few-fold by concentrations of $\beta$-ketoadipate that cause a 50 -fold induction of enzymes of the $\beta$-ketoadipate pathway (Parke $\&$ Ornston, 1976). Utilization of $\beta$-ketoadipate as a growth substrate is limited by transport of the compound into $P$. putida (Stanier, 1947). Transport of adipate by the system is inhibited by a number of dicarboxylic acids (Ornston $\&$ Parke, 1976), and this raises the possibility that the system is, in whole or in part, a general transport system that acts on dicarboxylic acids of the tricarboxylic acid cycle.

In this paper, we summarize kinetic and physical studies supporting the conclusion that $\beta$-ketoadipate is the natural substrate of the transport system which is structurally and functionally unlike other dicarboxylic acid transport systems of fluorescent pseudomonads 
METABOLITES

$p$-Hydroxybenzoate<smiles>CC(C)c1c(O)ccc(O)c1C(=O)[O-]</smiles>

Protocatechuate<smiles>CC(C(=O)[O-])C(=O)[O-]</smiles>

$\beta$-Carboxy-cis,cis-muconate<smiles>C[C@H](C(=O)[O-])[C@H](C)C(=O)OC(=O)[O-]</smiles>

$\boldsymbol{\gamma}$-Carboxymuconolactone<smiles>O=C([O-])CC1CCC(=O)O1</smiles>

$\beta$-Ketoadipate enol-lactone<smiles>C[C@H](C(=O)[O-])C(=O)CCC(=O)[O-]</smiles>

$\beta$-Ketoadipate<smiles>CC(C(=O)OCC(=O)[O-])[C@@H](C)C(=O)O</smiles>

$\beta$-Ketoadipate succinyl-CoA

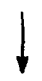

Succinate + Acetyl-CoA
ENZYMES

Protocatechuate

3,4-dioxygenase

$\beta$-Carboxymuconate lactonizing enzyme

$\boldsymbol{\gamma}$-Carboxymuconolactone decarboxylase

$\beta$-Ketoadipate enol-lactone hydrolase

$\beta$-Ketoadipate succinyl-CoA

$\beta$-Ketoadipate transferase

\section{INDUCERS}

(in fluorescent

pseudomonads)

Protocatechuate
$\beta$-Ketoadipate

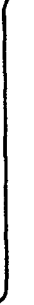


(Dubler et al., 1974; Stinson et al., 1976). In addition, we show that the inducible $\beta$-ketoadipate transport system is widely distributed among bacteria that govern the $\beta$-ketoadipate pathway by the induction mechanisms employed by representatives of $\boldsymbol{P}$. putida.

\section{METHODS}

Strains. Strain PRS2000 was selected from strain 90 of Pseudomonas putida, biotype A (Stanier et al., 1966), on the basis of its ability to grow at the expense of cis,cis-muconate. This property proved to be genetically unstable, and now the two strains are phenotypically indistinguishable (Meagher et al., 1972). Strain PRS2015, derived from strain PRS2000, carries a deletion in $c a t B$, the structural gene for muconate lactonizing enzyme (Wheelis \& Ornston, 1972). Sequential transfer of PRS2015 cultures between growth media containing succinate as a sole carbon source and growth media containing $\beta$-ketoadipate as sole carbon source enriched strain PRS2178 which constitutively forms the $\beta$-ketoadipate transport system and the three enzymes that convert $\beta$-carboxymuconate to $\beta$-ketoadipate (Parke $\&$ Ornston, 1976). Natural isolates of $P$. putida and Pseudomonas fuorescens are represented by the strain designations given by Stanier et al. (1966).

Culture conditions. All cultures were grown overnight at $30^{\circ} \mathrm{C}$ in defined mineral medium (Ornston \& Stanier, 1966) from a $1 \%(\mathrm{v} / \mathrm{v})$ inoculum grown in the same medium. Aeration was provided by shaking $500 \mathrm{ml}$ flasks containing $150 \mathrm{ml}$ cultures in a New Brunswick environmental incubator. Carbon sources were sterilized in an autoclave, stored as $0.5 \mathrm{M}$ solutions, and added aseptically just before inoculation to give concentrations of $5 \mathrm{mM}$ ( $p$-hydroxybenzoate) or $10 \mathrm{mM}$ (succinate or glucose). Cultures were harvested in stationary phase; transport activity is most fully expressed in such cells, and the activity remains constant in cell suspensions stored at room temperature in $0.85 \%(\mathrm{w} / \mathrm{v}) \mathrm{NaCl}$ for $2 \mathrm{~d}$.

Transport assay. Cultures were harvested at $20^{\circ} \mathrm{C}$ by centrifugation, washed twice with $0.85 \% \mathrm{NaCl}$, and resuspended in the saline solution to a final concentration of $12.5 \mathrm{mg} \mathrm{dry}^{\mathrm{tt} \mathrm{ml}} \mathrm{ml}^{-1}$. The concentrated cell suspension was diluted 10-fold into buffer for transport assays; the final cell concentration of $1.25 \mathrm{mg}$ dry wt $\mathrm{ml}^{-1}$ corresponded to a turbidity of $\mathbf{3 7 5}$ Klett Units when measured in a Klett-Summerson meter equipped with a no. 66 filter. Unless otherwise stated, the assay buffer was $0.2{\mathrm{M}-\mathrm{NaH}_{2}} \mathrm{PO}_{4}, \mathrm{pH} 5 \cdot 7$, at $35^{\circ} \mathrm{C}$. Transport was initiated by addition of $\left[1,6^{14} \mathrm{C}\right]$ adipate to a final concentration of $1.0 \mu \mathrm{M}$. At intervals, $0.2 \mathrm{ml}$ samples were taken and rapidly filtered through prewetted membrane filters (Millipore; no. PHWP02500). Samples were washed three times with $2 \mathrm{ml}$ assay buffer; the filter was blotted dry, and radioactivity was counted in a Beckman LS3133 liquid scintillation spectrometer. Influx is expressed as pmol adipate (mg dry wt) ${ }^{-1} \mathrm{~min}^{-1}$. All values were corrected for non-specific binding of radioactive adipate determined by addition of [14C $\mathrm{C}$ adipate directly to whole cells trapped on a membrane filter, followed immediately by the standard washing procedure. The correction represented less than $5 \%$ of full activity.

Inhibitor studies. Each inhibitor was incubated with the cell suspension for $5 \mathrm{~min}$ prior to initiation of the transport reaction. Since arsenate effects cannot be determined in the presence of phosphate buffers, a buffer containing 0.01 $\mathrm{M}$-pyridine and $0.1 \mathrm{M}-\left(\mathrm{NH}_{4}\right)_{2} \mathrm{SO}_{4}, \mathrm{pH} 5.7$, was substituted for the assay buffer in experiments involving arsenate. Anaerobiosis was achieved by placing reaction vessels containing the cell suspensions in vacuo and then filling each vessel with purified $\mathrm{N}_{2}$ to $35 \mathrm{kPa}$. Cells were not preincubated with $\beta$-ketoadipate, succinate or acetate prior to kinetic studies with these compounds. Rather, the compounds were added simultaneously with the radioactive adipate solution.

Membrane vesicles. Membrane vesicles were prepared according to the method of Kaback (1971) from overnight cultures grown at the expense of $10 \mathrm{~mm}$-glucose. As determined by the method of Lowry, the protein concentration in the vesicle preparations was 3 to $4 \mathrm{mg} \mathrm{ml}^{-1}$; the intravesicular volume of such preparations has been estimated to be $2 \mu \mathrm{l}$ (mg protein) ${ }^{-1}$ (Kaback \& Barnes, 1971). Transport rates in membrane vesicles were determined by the addition of $\left[{ }^{14} \mathrm{C}\right]$ adipate or $\left[{ }^{14} \mathrm{C}\right]$ succinate to a reaction vessel containing $75 \mu \mathrm{g}$ vesicle protein, $10 \mathrm{~mm}-\mathrm{MgSO}_{4}, 20 \mathrm{~mm}$-D-lactate and $50 \mathrm{~mm}-\mathrm{Na}_{2} \mathrm{HPO}_{4}, \mathrm{pH} 6 \cdot 6$, in a final volume of $50 \mu \mathrm{l}$. The reaction was terminated after $2 \mathrm{~min}$ by addition of $2.0 \mathrm{ml} \mathrm{0.1} \mathrm{M-LiCl}$. The vesicles were collected by filtration, washed once with $2.0 \mathrm{ml} 0.1 \mathrm{M}-\mathrm{LiCl}$, and the filters were placed in $10 \mathrm{ml}$ of New England Nuclear Biofluor for counting in a Beckman LS3133 liquid scintillation spectrometer.

Chemicals. $\left[1,6-{ }^{14} \mathrm{C}\right]$ Adipic acid, specific activity $7.6 \mathrm{mCi} \mathrm{mmol}^{-1}(280 \mathrm{MBq} \mathrm{mmol}-1)$, was purchased from ICN Pharmaceuticals. $\left[1,4^{14} \mathrm{C}\right.$ Succinic acid, specific activity $35.5 \mathrm{mCi} \mathrm{mmol}^{-1}\left(1.31 \mathrm{GBq} \mathrm{mmol}{ }^{-1}\right)$, was purchased from New England Nuclear. $\beta$-Ketoadipic acid was synthesized according to the method of Riegel \& Lilienfeld (1945). All other chemicals were obtained from commercial sources. 


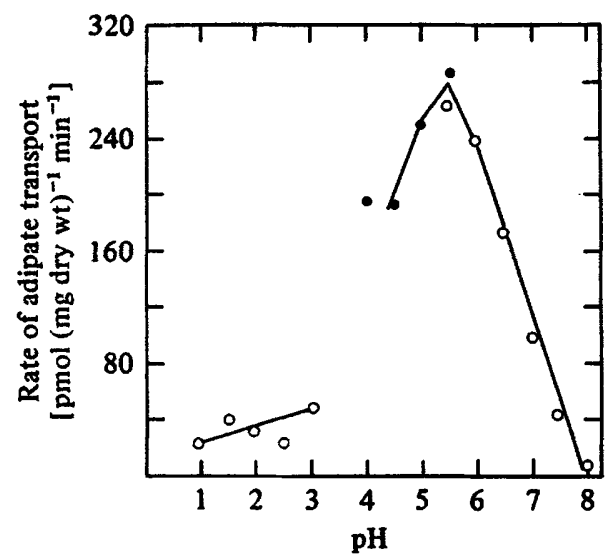

Fig. 2

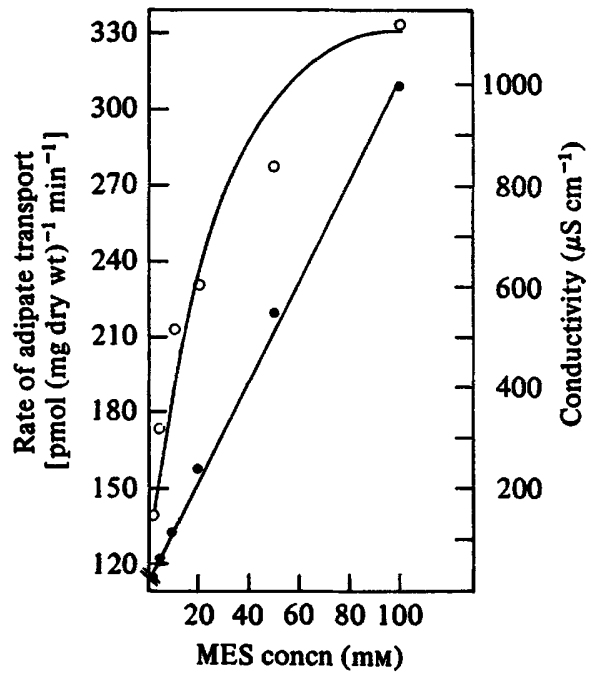

Fig. 3

Fig. 2. Effect of pH on the initial rate of adipate transport in $P$. putida strain PRS2178. The transport assay was conducted at $23^{\circ} \mathrm{C}$ using a $1.0 \mathrm{ml}$ cell suspension $\left(1.25 \mathrm{mg} \mathrm{dry} \mathrm{wt} \mathrm{ml}^{-1}\right)$ in the appropriate buffer. The reaction was initiated by addition of $1.0 \mu \mathrm{M}-\left[{ }^{14} \mathrm{C}\right]$ adipate, and samples $(0.25 \mathrm{mg}$ dry $w t)$ were taken at 30 and $60 \mathrm{~s}$. The buffers were $0.2 \mathrm{M}$-sodium phosphate $(O)$ and 10 mM-pyridine plus $0.2 \mathrm{M}$-sodium phosphate (O). All buffers were $0.2 \mathrm{M}$ with respect to phosphate.

Fig. 3. Influence of ionic strength on the initial rate of adipate transport in $P$. putida strain PRS2178. Cells were harvested and washed as described in Table 1. Transport assays $(O)$ were conducted at $35^{\circ} \mathrm{C}$ and conductivity (O) was measured using a YSI model 31 Conductivity Bridge. Cells were incubated at a concentration of $1.25 \mathrm{mg}$ dry $\mathrm{wt} \mathrm{ml}^{-1}$ in the appropriate buffer for 5 min prior to the initiation of the reaction. Buffer $\mathrm{pH}$ was adjusted to $\mathrm{pH} 5.7$ with $0.5 \mathrm{M}$-Tris.

\section{RESULTS}

\section{Influence of temperature, $\mathrm{pH}$ and ionic strength}

The transport-constitutive strain, $P$. putida PRS2178, exhibits maximal activity of adipate transport after growth on 10 mM-glucose (Ornston \& Parke, 1976). In this strain, the initial rate of transport increased with increasing temperature. It reached an optimum of $350 \mathrm{pmol}$ ( $\mathrm{mg}$ dry cell wt) $)^{-1} \mathrm{~min}^{-1}$ between 40 and $45^{\circ} \mathrm{C}$, i.e. $10^{\circ} \mathrm{C}$ above the optimum temperature for growth of $P$. putida (Stanier et al., 1966). An Arrhenius plot of the temperature dependence of transport yielded an activation energy of $6 \mathrm{kcal} \mathrm{mol}^{-1}\left(25 \mathrm{~kJ} \mathrm{~mol}^{-1}\right)$.

The pH optimum for transport in $0.2 \mathrm{M}$-phosphate was pH 5.5 (Fig. 2).

Adipate transport was stimulated by a variety of salts (Table 1). With the exception of the chlorides of $\mathrm{Mn}^{2-}, \mathrm{NH}_{4}{ }^{+}$and $\mathrm{Ca}^{2+}$ which were inhibitory, all salts tested increased the rate of transport. Stimulation of the transport system did not appear to be dependent on one particular ion, but rather on ionic strength. This hypothesis was tested by employing assay buffers containing various concentrations of $2-(\mathrm{N}$-morpholino)ethanesulphonate (MES) at pH 5.7 (Fig. 3). Increasing the concentration of this zwitterionic buffer from 2 to $100 \mathrm{mM}$ increased the rate of transport more than $2 \cdot 5$-fold. A further increase in the buffer concentration did not substantially change the transport rate. A 3- to 4-fold increase in transport activity was also observed when $10 \mathrm{~mm}$-pyridine ( $\mathrm{pH} \mathrm{6.0)}$ was used as a buffer and either $\left(\mathrm{NH}_{4}\right)_{2} \mathrm{SO}_{4}$ or $\mathrm{NaH}_{2} \mathrm{PO}_{4}$ was added in concentrations of up to $0.2 \mathrm{M}$.

Inhibition by organic acids

The $K_{\mathrm{m}}$ for adipate transport in strain PRS2178 was $0.23 \mathrm{mM}$ (Fig. 4). $\beta$-Ketoadipate was a competitive inhibitor of adipate transport with a $K_{\mathrm{t}}$ of $0.04 \mathrm{mM}$ (Fig. 4). The $K_{\mathrm{t}}$ was 5 -fold 
Table 1. Effect of various salts on the initial rate of adipate transport in $P$. putida strain PRS2178

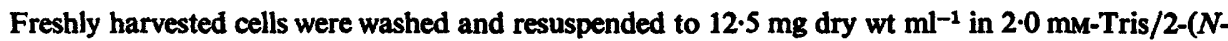
morpholino)ethanesulphonate (MES), pH 5.7. The cell suspension was then diluted to $1.25 \mathrm{mg}$ dry wt $\mathrm{ml}^{-1}$ in $2.0 \mathrm{mM}$-Tris/MES containing the various salts at $100 \mathrm{mM}$. All buffers were adjusted in pH 5.7. Cells were incubated with the appropriate buffer at $35^{\circ} \mathrm{C}$ for $5 \mathrm{~min}$ prior to initiation of the transport assay. Samples were taken at 30,60 and $90 \mathrm{~s}$, and the washing procedure employed the same salt-containing buffer.

\begin{tabular}{|c|c|}
\hline Salt added & $\begin{array}{l}\text { Transport rate } \\
\text { [pmol (mg dry } \\
\text { wt) })^{-1} \mathrm{~min}^{-1} \text { ] }\end{array}$ \\
\hline $\begin{array}{l}\mathrm{None} \\
\mathrm{NaCl} \\
\mathrm{Na}_{2} \mathrm{SO}_{4} \\
\mathrm{NaH}_{2} \mathrm{PO}_{4} \\
\mathrm{KH}_{2} \mathrm{PO}_{4} \\
\mathrm{LiCl} \\
\mathrm{MgSO}_{4} \\
\mathrm{MnCl}_{2} \\
\mathrm{MnSO}_{4} \\
\left(\mathrm{NH}_{4}\right)_{2} \mathrm{SO}_{4} \\
\mathrm{NH}_{4} \mathrm{Cl} \\
\mathrm{CaCl}_{2}\end{array}$ & $\begin{array}{r}120 \\
180 \\
210 \\
350 \\
420 \\
190 \\
180 \\
10 \\
150 \\
130 \\
60 \\
40\end{array}$ \\
\hline
\end{tabular}

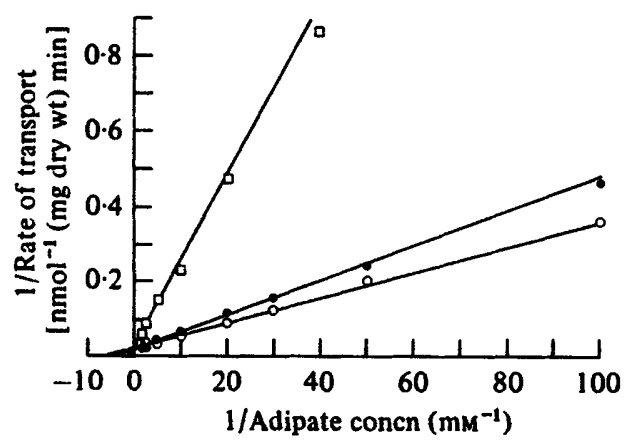

Fig. 4. Competitive inhibition of adipate transport by $\beta$-ketoadipate in $P$. putida strain PRS2178. Samples $(0.25 \mathrm{mg}$ dry wt) were taken at $1 \mathrm{~min}$ in the absence of $\beta$-ketoadipate $(O)$ or in the presence of $10 \mu \mathrm{M}(\mathrm{O})$ or $100 \mu \mathrm{M}(\square) \beta$-ketoadipate. The buffer employed was $0.2 \mathrm{M}-\mathrm{NaH}_{2} \mathrm{PO}$, pH 5.7 at $35^{\circ} \mathrm{C}$. $\beta$-Ketoadipate was added simultaneously with the various concentrations of $\left[{ }^{14} \mathrm{C}\right]$ adipate.

lower than the $K_{\mathrm{m}}$ for adipate transport, and thus it appeared that the affinity of the transport system for $\beta$-ketoadipate was higher than its affinity for adipate.

Addition of succinate, acetate or a variety of other organic acids to cells which had been preloaded with [ $\left.{ }^{14} \mathrm{C}\right]$ adipate led to rapid loss of the intracellularly accumulated adipate (Ornston \& Parke, 1976). Succinate was found to be a competitive inhibitor of adipate influx (Fig. $5 a$ ) and acetate was a non-competitive inhibitor (Fig. $5 b$ ). The $K_{1}$ values were 1.3 and $5.3 \mathrm{~mm}$, respectively.

\section{Effects of inhibitors}

The transport of adipate was energy-dependent and inhibited by a variety of compounds (Table 2). Cyanide and azide, which function at the level of cytochrome oxidase, were effective in blocking adipate transport. Of these two, azide, which may also act as a conductor of protons across the bacterial membrane, was most effective. Arsenate, an uncoupler of oxidative phosphorylation, and anaerobiosis also inhibited the transport of adipate. The proton conductors 2,4-dinitrophenol, pentachlorophenol and carbonyl cyanide $m$-chlorophenylhydrazone were the most effective of the inhibitors tested. 


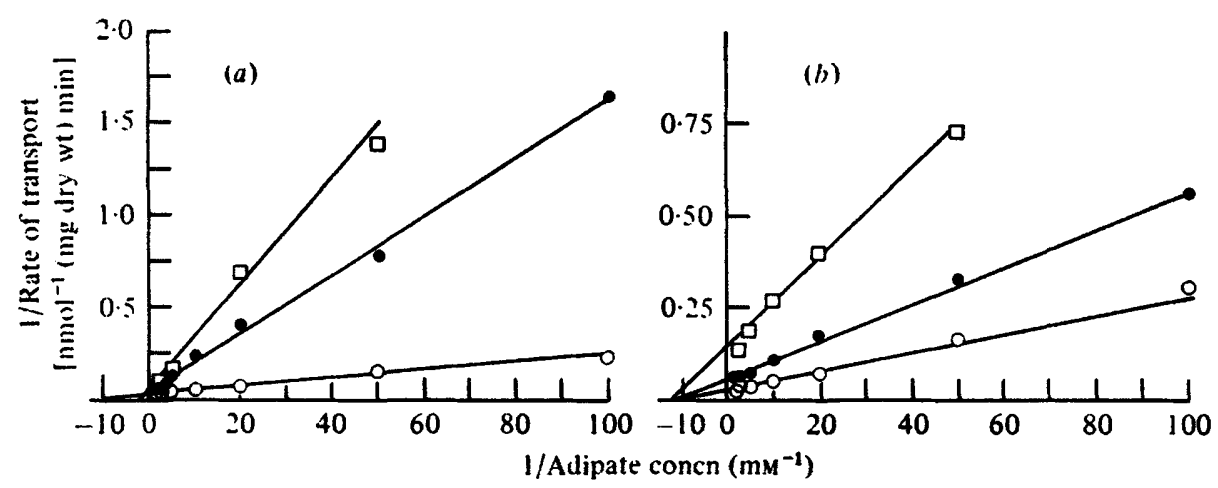

Fig. 5. Kinetics of inhibition of adipate transport in P. putida strain PRS2178 by succinate (a) and acetate $(b)$. Inhibitors were added simultaneously with $1 \mu \mathrm{M}-\left[{ }^{1{ }^{4}} \mathrm{C}\right]$ adipate at zero time. Samples were taken at $1 \mathrm{~min}$. The buffer was $0.2 \mathrm{M}-\mathrm{NaH}_{2} \mathrm{PO}_{4}, \mathrm{pH} 5.7$ at $35^{\circ} \mathrm{C}$. (a) Double-reciprocal plot showing inhibition of adipate transport by $5 \mathrm{mM}(\Theta)$ or $10 \mathrm{~mm}(\square)$ succinate; the control with no added succinate $(O)$ is also shown. (b) Double-reciprocal plot showing inhibition of adipate transport by $10 \mathrm{~mm}(\odot)$ or $20 \mathrm{~mm}(\square)$ acetate; the control with no added acetate $(O)$ is also shown.

Table 2. Effect of inhibitors on the initial rate of adipate transport in P. putida strain PRS2178

Inhibitors were added to cell suspensions $5 \mathrm{~min}$ prior to initiation of the assay. 2,4-Dinitrophenol, carbonyl cyanide $m$-chlorophenylhydrazone and pentachlorophenol were dissolved in $95 \%$ ethanol. Inhibitors were prepared as 100 times concentrated stock solutions, and an equal amount of ethanol added to each control tube inhibited activity by no more than $10 \%$. Anaerobiosis was achieved by placing the reaction vessels containing the cell suspensions in vacuo and then filling each vessel with purified $\mathrm{N}_{2}$ to $35 \mathrm{kPa}$.

\begin{tabular}{lcc}
\multicolumn{1}{c}{ Inhibitor } & Concn $(\mathrm{mM})$ & Inhibition $(\%)$ \\
Cyanide & 10 & 31 \\
& 100 & 79 \\
Azide & 10 & 90 \\
Arsenate & 10 & 59 \\
& 50 & 89 \\
Anaerobiosis & - & 80 \\
2,4-Dinitrophenol & 0.5 & 88 \\
& $5 \cdot 0$ & 94 \\
Carbonyl cyanide & 0.001 & 10 \\
m-chlorophenylhydrazone & 0.010 & 88 \\
Pentachlorophenol & 0.01 & 15 \\
& $0 \cdot 10$ & 92 \\
Iodoacetate & $0 \cdot 1$ & 11 \\
& 1.0 & 28 \\
p-Chloromercuribenzoate & 0.1 & 62 \\
N-Ethylmaleimide & 1.0 & 98 \\
\end{tabular}

The electron transport inhibitors antimycin A, rotenone and o-phenanthroline, and the ATPase inhibitor $N, N^{\prime}$-dicyclohexylcarbodiimide did not block adipate transport. However, this lack of inhibition may reflect failure of these compounds to penetrate the P. putida outer membrane.

Thiol reagents, especially $p$-chloromercuribenzoate, caused a reversible inhibition of adipate transport. After inhibition by $0.1 \mathrm{~mm}$-p-chloromercuribenzoate (Table 2), addition of a 10-fold molar excess of dithiothreitol restored $80 \%$ of normal activity; addition of higher concentrations of dithiothreitol did not increase the recovery of activity. 
Table 3. Adipate and succinate accumulation in membrane vesicles prepared from $P$. putida strains PRS2000 and PRS2178

Membrane vesicles $\left(75 \mu \mathrm{g}\right.$ protein) were incubated at $30^{\circ} \mathrm{C}$ with $20 \mathrm{~mm}$-D-lactate as an energy source. Either $0.1 \mathrm{~mm}-\left[{ }^{14} \mathrm{C}\right]$ adipate or $0.06 \mathrm{~mm}-\left[{ }^{24} \mathrm{C}\right]$ succinate was added. After $2 \mathrm{~min}$, vesicles were collected by filtration. Membrane vesicles were estimated to contain $2 \mu$ l intravesicular volume (mg protein $)^{-1}$ (Kaback \& Barnes, 1971).

\begin{tabular}{ccc} 
Strain & Internal concn/external concn \\
\cline { 2 - 3 } Pdipate & Succinate \\
PRS2178 & 1.6 & 3.2 \\
& 11.5 & 3.3
\end{tabular}

\section{Location of the $\beta$-ketoadipate transport protein}

Bacterial transport systems generally fall into two categories, shock-resistant and shocksensitive (Berger \& Heppel, 1974). Substrate binding proteins are often released from the periplasmic space when shock-sensitive systems are subjected to osmotic shock (Heppel, 1967). The activity of shock-resistant systems, particularly those sensitive to uncouplers and thiol reagents (Berger \& Heppel, 1974), may be recovered in cell-free preparations of membrane vesicles (Kaback, 1971). The effects of osmotic shock treatment and membrane vesicle formation were therefore investigated using glucose-grown cultures of the transportconstitutive strain, PRS2178.

The constitutive cells were subjected to osmotic shock by the technique described by Stinson et al. (1976). Osmotically shocked cells transported adipate at rates equal to those of untreated cells, and the shock fluid failed to bind $\left[{ }^{14} \mathrm{C}\right]$ adipate in equilibrium dialysis experiments.

After a 2 min exposure to $\left[{ }^{14} \mathrm{C}\right]$ adipate, membrane vesicles prepared from uninduced cultures of the constitutive mutant strain PRS2178 accumulated the compound to a level 7-fold higher than that found with vesicles prepared from uninduced cultures of the wildtype strain PRS2000 (Table 3). Vesicles prepared from the two cultures accumulated equal amounts of succinate after 2 min (Table 3); since the vesicles were prepared from glucosegrown cultures, the accumulation represents basal levels of succinate transport and not the inducible dicarboxylic acid transport system reported by Dubler et al. (1974). Because the levels of succinate accumulation were equally low in both preparations (Table 3), the high level of adipate transport by vesicles from the constitutive strain cannot be attributed to a general dicarboxylic acid transport system that acts on succinate.Vesicles prepared from strain PRS2178 exhibited a $V_{\max }$ of $1.7 \mathrm{nmol} \mathrm{min}^{-1}$ (mg membrane protein)-1 and a $K_{\mathrm{m}}$ of $0.14 \mathrm{mM}$ with adipate, close to the $K_{\mathrm{m}}$ value of $0.23 \mathrm{mM}$ that we observed with adipate and whole cells of the same strain. Either D-lactate or phenazine methosulphate plus ascorbate could be used as an energy source.

\section{Biological distribution of the $\beta$-ketoadipate transport system}

We examined expression of the transport system in representatives of different biotypes of $\boldsymbol{P}$. putida and $\boldsymbol{P}$. fluorescens, organisms in which structural genes for enzymes of the $\beta$ ketoadipate pathway have diverged considerably (Patel \& Ornston, 1976). All the strains (Table 4) regulate the pathway with the induction pattern found in $P$. putida, biotype A (Ornston, 1971). As a precaution against distortions that might be caused by the metabolic assimilation of adipate we selected, in so far as possible, strains that are unable to grow on it (Stanier et al., 1966).

Representatives of each $P$. putida and $P$. fluorescens biotype had increased rates of adipate transport after growth with the inducing carbon source $p$-hydroxybenzoate (Table 4$)$. The induced rates of transport in the different $\boldsymbol{P}$. putida isolates were fairly constant, ranging 


\section{Table 4. Comparison of induced and uninduced rates of adipate transport} in $P$. putida and $P$. fluorescens

\begin{tabular}{|c|c|c|c|c|c|c|}
\hline \multirow[b]{2}{*}{ Organism } & \multirow[b]{2}{*}{ Biotype } & \multirow{2}{*}{ Strain* } & \multirow{2}{*}{$\begin{array}{c}\text { Ability to } \\
\text { utilize adipate } \\
\text { as carbon source }\end{array}$} & \multicolumn{2}{|c|}{$\begin{array}{l}\text { Rate of uptake of }\left[{ }^{14} \mathrm{C} \text { adipate }\right. \\
\left.\text { [pmol (mg dry wt) }{ }^{-1} \mathrm{~min}^{-1}\right]\end{array}$} & \multirow[b]{2}{*}{$\begin{array}{l}\text { Induced rate/ } \\
\text { uninduced rate }\end{array}$} \\
\hline & & & & $\begin{array}{l}\text { Cells grown on } \\
\text { succinate }\end{array}$ & $\begin{array}{l}\text { Cells grown on } \\
p \text {-hydroxybenzoate }\end{array}$ & \\
\hline $\begin{array}{l}P . \text { putida } \\
P . \text { putida } \\
P . \text { putida } \\
P . \text { putida } \\
P \text {. putida }\end{array}$ & $\begin{array}{l}\mathbf{A} \\
\mathbf{A} \\
\mathbf{B} \\
\mathbf{B} \\
\mathbf{B}\end{array}$ & $\begin{array}{l}\text { PRS2000 } \\
\text { PRS2015 } \\
96 \\
98 \\
110\end{array}$ & $\begin{array}{l}- \\
- \\
- \\
-\end{array}$ & $\begin{array}{r}15 \\
6 \\
11 \\
5 \\
10\end{array}$ & $\begin{array}{l}34 \\
37 \\
40 \\
31 \\
43\end{array}$ & $\begin{array}{l}2 \cdot 3 \\
6 \cdot 2 \\
3 \cdot 6 \\
6 \cdot 2 \\
4 \cdot 3\end{array}$ \\
\hline $\begin{array}{l}P . \text { fluorescens } \\
P . \text { fluorescens } \\
P . \text { fluorescens } \\
P . \text { fluorescens } \\
P . \text { fluorescens } \\
P . \text { fluorescens }\end{array}$ & $\begin{array}{l}\mathbf{A} \\
\mathbf{B} \\
\mathbf{B} \\
\mathbf{C} \\
\mathbf{D} \\
\mathbf{E}\end{array}$ & $\begin{array}{l}188 \\
406 \\
408 \\
214 \\
31 \\
36\end{array}$ & $\begin{array}{l}- \\
- \\
\bar{t} \\
-\end{array}$ & $\begin{array}{l}8 \\
3 \\
8 \\
2 \\
1 \\
3\end{array}$ & $\begin{array}{r}64 \\
112 \\
184 \\
106 \\
19 \\
30\end{array}$ & $\begin{array}{r}8 \\
37 \\
23 \\
53 \\
19 \\
10\end{array}$ \\
\hline
\end{tabular}

- Strain PRS2000 is a wild-type representative of $P$. putida biotype A. Strain PRS2015 was derived from strain PRS2000 and is the parental strain of the transport-constitutive mutant, strain PRS2178 (Parke \& Ornston, 1976). Other designations are according to Stanier et al. (1966).

from 31 to $43 \mathrm{pmol}$ (mg dry wt) ${ }^{-1} \mathrm{~min}^{-1}$. In contrast, the uninduced rates, which may reflect the non-specific contribution of other transport systems, varied by a factor of 3 , from 5 to $15 \mathrm{pmol}$ (mg dry wt) ${ }^{-1} \mathrm{~min}^{-1}$. The background rate of adipate transport in uninduced cultures of $P$. fluorescens was relatively low, ranging from 1 to $8 \mathrm{pmol}(\mathrm{mg} \text { dry wt) })^{-1}$ $\min ^{-1}$. The low background rate in the uninduced $\boldsymbol{P}$. fluorescens cultures allowed measurement of substantial increases in transport activity after growth under inducing conditions. The extreme example is an induction of more than 50-fold observed in strain 214, a representative of $\boldsymbol{P}$. fluorescens, biotype $\mathrm{C}$, after growth with $\boldsymbol{p}$-hydroxybenzoate.

\section{Transport limits the rate of growth of $P$. putida on $\beta$-ketoadipate}

Stanier's studies of simultaneous adaptation demonstrated that the transport of $\beta$ ketoadipate limits the rate of its respiration by induced $P$. putida cultures (Stanier, 1947). Barriers to the permeability of $\beta$-ketoadipate were also revealed by growth experiments. Mandelate and $p$-hydroxybenzoate, compounds metabolized via $\beta$-ketoadipate, allowed growth of wild-type $P$. putida cultures with respective doubling times of 60 and 75 min when supplied at concentrations of $5 \mathrm{mM}$. The same concentration of $\beta$-ketoadipate supported growth of the wild-type strain with a doubling time of $140 \mathrm{~min}$. Even the 10 -fold overproduction of the transport system in the constitutive strain PRS2178 (Parke \& Ornston, 1976) reduced the doubling time with $5 \mathrm{~mm}-\beta$-ketoadipate only to $85 \mathrm{~min}$, longer than the doubling time observed with mandelate or $p$-hydroxybenzoate.

\section{DISCUSSION}

The primary physiological function of a transport system often is assumed to be the uptake of nutrients across the cell membrane, but components of transport systems may also participate in chemotaxis (Kalckar, 1976) and in the regulation of the concentration of intracellular metabolites (Weill-Thevenet et al., 1979). Genetic approaches have defined overlapping functions in some transport systems. For example, dysfunctions in one gal gene inactivate both galactose transport and galactose chemotaxis in Escherichia coli; mutations in another gal gene destroy galactose transport activity but leave the chemotactic response intact (Silhavy et al., 1974). These observations show that components of a transport system may function and, indeed, may be selected even if they confer little or no direct nutritional benefit by transporting metabolites. 
The wild-type $\beta$-ketoadipate transport system is unusual in that its direct nutritional contribution is marginal at best. The inability of induced Pseudomonas cultures to respire with exogenous $\beta$-ketoadipate served as a classical demonstration of a permeability barrier (Stanier, 1947), and the limitation is illustrated by the fact that wild-type cells grow with $\beta$-ketoadipate more slowly than with aromatic precursors of this compound. The limited nutritional contribution of the $\beta$-ketoadipate transport system raised possibilities that $\beta$-ketoadipate is not its natural substrate and that the transport system does not confer a selective benefit in the niche of fluorescent pseudomonads. Our approach to these questions was (i) to determine experimental conditions that favoured optimal activity of the transport system, (ii) to distinguish between the $\beta$-ketoadipate system and the other known dicarboxylic acid transport systems of Pseudomonas and (iii) to explore the biological distribution of the $\beta$-ketoadipate transport system.

Conditions favouring optimal transport activity. The $\beta$-ketoadipate transport system possesses several properties that normally are associated with electrochemically driven membrane transport systems. Maximal transport was observed at the relatively low pH of 5.5 (Fig. 2), suggesting the contribution of a high external proton gradient to the driving of transport. The $K_{\mathrm{m}}$ of the system at pH 5.7 was $0.23 \mathrm{mM}$ (Fig. 4), close to the value of $0.2 \mathrm{mM}$ observed with the same transport system at pH 6.8 (Ornston \& Parke, 1976). High ionic strength is required for maximal transport activity (Fig. 3). A variety of ions (Table 1) will satisfy this requirement indicating that, while a proton gradient is essential, no one particular cation or anion is required. Also, the most efficient inhibitors of adipate transport are agents which promote the transfer of protons across the membrane and thus destroy the proton gradient (Table 2). Therefore, the adipate transport system probably is an electrochemically driven system in which protons are co-transported with adipate to maintain electroneutrality.

Under optimal conditions the $\beta$-ketoadipate transport system acts effectively on the substrate analogue adipate. Cultures of the transport-constitutive mutant strain PRS2178 can concentrate adipate with a $V_{\max }$ of $40 \mathrm{nmol} \mathrm{min}^{-1}$ (mg dry wt)-1 to achieve intracellular concentrations that exceed extracellular concentrations by more than 100-fold (Ornston \& Parke, 1976). It should be noted that adipate accumulation is not favoured under conditions that favour the growth of Pseudomonas cultures: under normal growth conditions, the activity of the transport system in induced wild-type $P$. putida cultures is less than $5 \%$ of that found under optimal assay conditions. This observation strengthens the inference that the primary physiological function of the transport system probably is not the uptake of $\beta$-ketoadipate as a growth substrate. Indeed, the data raise the possibility that optimal transport activity is observed under extreme physical conditions that may dissociate the transport system from normal regulation.

Characteristics that distinguish the $\beta$-ketoadipate transport system. Transport of radioactive adipate by the $\beta$-ketoadipate transport system is inhibited by a number of dicarboxylic acids and, on the basis of these observations alone, the system might be regarded as a general transport system that acts on a range of dicarboxylic acids. Evidence to the contrary, identifying $\beta$-ketoadipate as the specific substrate of the system, has been physiological and genetic (Ornston \& Parke, 1976). To this may now be added the observation that $\beta$-ketoadipate is a powerful competitive inhibitor of adipate transport by the system: its apparent affinity for $\beta$-ketoadipate is 5 -fold greater than its affinity for adipate. The apparent affinity of the transport system for succinate is one-sixth of its affinity for adipate and one-thirtieth of its apparent affinity for $\beta$-ketoadipate. Therefore, kinetic evidence buttresses the earlier conclusion that the system is specifically associated with $\beta$-ketoadipate.

Adipate transport is reversibly inhibited by thiol reagents, a common feature of membrane carrier transport in prokaryotes (Kaback \& Barnes, 1971; Berger \& Heppel, 1974). Activity of the $\beta$-ketoadipate transport system was recovered in membrane vesicles, and on this basis the system may be distinguished physically from the shock-sensitive dicarboxylic 
acid transport system of Pseudomonas aeruginosa (Stinson et al., 1976). Membrane vesicles from mutant strain PRS2178 contained elevated levels of the $\beta$-ketoadipate transport activity, yet transported succinate no more rapidly than vesicles from the wild-type strain (Table 3). Hence, the $\beta$-ketoadipate transport system is distinct from the inducible $\boldsymbol{P}$. putida malate-succinate--formate transport system described by Dubler et al. (1974).

Biological distribution of the $\beta$-ketoadipate transport system. Earlier observations (Parke $\&$ Ornston, 1976) indicated that the $\beta$-ketoadipate transport system is induced only a fewfold in wild-type $P$. putida cultures. Since $\beta$-ketoadipate elicits a 50 -fold induction of enzymes of the $\beta$-ketoadipate pathway, the evidence prompted the speculation that the transport system is an evolutionary vestige that has been inactivated by mutation because it no longer is selected in the niche of fluorescent pseudomonads. On the other hand, if the transport system were selected it would be conserved, even in fluorescent Pseudomonas species in which genes for the $\beta$-ketoadipate pathway have diverged considerably. It was possible to explore this question because immunological studies (Patel \& Ornston, 1976) give a measure of the evolutionary divergence of the structural gene for $\gamma$-carboxymuconolactone decarboxylase, an enzyme that shares a regulatory gene with the $\beta$-ketoadipate transport system. The decarboxylase subunit contains about 110 amino acid residues (Parke, 1979), and the respective decarboxylases of $\boldsymbol{P}$. fluorescens and $\boldsymbol{P}$. putida differ in at least four antigenic determinants (Patel \& Ornston, 1976). Most mutations have deleterious effects and, in the absence of selective pressure, the amount of mutation reflected in the divergence of the decarboxylase structural genes might be expected to have inactivated the $\beta$-ketoadipate transport system, in at least some representatives of the fluorescent Pseudomonas species. In fact, the inducible transport system was conserved in all members of $P$. putida and $\boldsymbol{P}$. fluorescens that were examined (Table 4). Furthermore, the low level of adipate transport in uninduced $P$. fluorescens cultures allowed a 50-fold induction of the transport system to be demonstrated (Table 4). These observations favour the conclusion that both the transport system and genes governing its biosynthetic regulation continue to be selected in the natural environment of fluorescent pseudomonads.

Since the direct nutritional contribution of the transport system is slight, it appears that its selective advantage might lie with its possible participation in chemotaxis and in its potential ability to regulate intracellular concentrations of the inducing metabolite, $\beta$ ketoadipate. There is reason to believe that the transport system may be associated with both functions. Dr M. Karimian (unpublished results) has shown that $\beta$-ketoadipate serves as a chemoattractant for wild-type $P$. putida cells. The chemotactic response is inducible, and mutations causing overproduction of the transport system render cells more sensitive to $\beta$-ketoadipate as a chemoattractant. This evidence suggests that the $\beta$-ketoadipate transport system may be a component of an inducible chemotactic system of the type found by Moulton \& Montie (1979) in Pseudomonas aeruginosa. In keeping with its postulated regulatory role, the $\beta$-ketoadipate transport system itself is highly regulated. Readily metabolized growth substrates both repress the synthesis and inhibit the activity of the transport system. Transport activity is highest in starved cells which adapt rapidly to growth with aromatic growth substrates via $\beta$-ketoadipate (Stanier, 1947). Thus, as has recently been suggested for Pseudomonas lysine transport systems (Weill-Thevenet et al., 1979), the $\beta$ ketoadipate transport system is likely to participate indirectly in the control of enzyme synthesis by governing the intracellular concentration of the regulatory metabolite, $\beta$ ketoadipate.

We are grateful to Donna G. Babbitt for skilful technical assistance. We also wish to thank H. R. Kaback and L. Patel for guidance in the preparation of membrane vesicles. This research was supported in part by National Science Foundation Grant PCM77-24884 and by Public Health Service Grant 1-RO1-GM25487 from the National Institute of General Medicine. J. M. Ondrako is the recipient of Public Health Service Grant F32AI05205 from 
the National Institute of Allergy and Infectious Diseases and a research fellowship from the Cystic Fibrosis Foundation, Atlanta, Georgia.

\section{REFERENCES}

Berger, E. A. \& Heppel, L. A. (1974). Differen mechanisms of energy coupling for the shocksensitive and shock-resistant amino acid permeases of Escherichia coli. Journal of Biological Chemistry 249, 7747-7755.

DUbleR, R. E., Toscano, W. A., JR \& HaRtline, R. A. (1974). Transport of succinate by Pseudomonas putida. Archives of Biochemistry and Biophysics 160, 422-429.

HEPPEL, L. A. (1967). Selective release of enzymes from bacteria. Science 156, 1451-1455.

KABACK, H. R. (1971). Bacterial membranes. Methods in Enzymology 22, 99-120.

KABACK, H. R. \& BARNes, E. M., JR (1971). Mechanisms of active transport in isolated membrane vesicles. 1I. The mechanism of energy coupling between $\mathrm{D}$-lactic dehydrogenase and $\beta$ galactoside transport in membrane preparations from Escherichia coli. Journal of Biological Chemistry 246, 5523-5531.

KaLCKAR, H. M. (1976). The periplasmic galactose receptor protein of Escherichia coli in relation to galactose chemotaxis. Biochimie 58, 81-85.

Meagher, R. B., McCorkle, G. M., Ornston, M. K. \& ORNSTUN, L. N. (1972). Inducible uptake system for $\beta$-carboxy-cis,cis-muconate in a permeability mutant of Pseudomonas putida. Journal of Bacteriology 111, 465-473.

Moulton, R. C. \& Montie, T. C. (1979). Chemotaxis by Pseudomonas aeruginosa. Journal of Bacteriology 137, 274-280.

ORNSTON, L. N. (1971). Regulation of catabolic pathways in Pseudomonas. Bacteriological Reviews 35, 87-116.

Ornston, L. N. \& Parke, D. (1976). Properties of an inducible uptake system for $\beta$-ketoadipate in Pseudomonas putida. Journal of Bacteriology 125, 475-488.

Ornston, L. N. \& Parke, D. (1977). The evolution of induction mechanisms in bacteria: insights derived from the study of the $\beta$-ketoadipate pathway. Current Topics in Cellular Regulation 12, 209-262.

Ornston, L. N. \& Stanier, R. Y. (1966). The conversion of catechol and protocatechuate to to $\beta$-ketoadipate by Pseudomonas putida. I. Biochemistry. Journal of Biological Chemistry 241, 3876-3886.
PARKe, D. (1979). Structural comparison of $\gamma$ carboxymuconolactone decarboxylase and muconolactone isomerase from Pseudomonas putida. Biochimica et biophysica acta 578, 145-154.

Parke, D. \& ORNSTON, L. N. (1976). Constitutive synthesis of enzymes of the protocatechuate pathway and of the $\beta$-ketoadipate uptake system in mutant strains of Pseudomonas putida. Journal of Bacteriology 126, 272-281.

Patel, R. N. \& ORnston, L. N. (1976). Immunological comparison of enzymes of the $\beta$-ketoadipate pathway. Archives of Microbiology 110, 27-36.

Riegel, B. \& Lilienfeld, W. M. (1945). The synthesis of $\beta$-keto esters by the decomposition of acylated malonic esters. Journal of the American Chemical Society 67, 1273-1275.

Silhavy, T. J., Boos, W. \& KalCKaR, H. M. (1974). The role of the Escherichia coli galactose-binding protein in galactose transport and chemotaxis. In Biochemistry and Sensory Functions, pp. 165-205. Edited by L. Jaenicke. New York: SpringerVerlag.

Stanier, R. Y. (1947). Simultaneous adaptation: a new technique for the study of metabolic pathways. Journal of Bacteriology 54, 339-348.

Stanier, R. Y., Palleroni, N. J. \& Doudoroff, M. (1966). The aerobic pseudomonads: a taxonomic study. Journal of General Microbiology 43, 159. 271.

Stinson, M. W., Cohen, M. A. \& Merrick, J. M. (1976). Isolation of dicarboxylic acid and glucosebinding proteins from Pseudomonas aeruginosa. Journal of Bacteriology 128, 573-579.

Thayer, J. R. \& Wheelis, M. L. (1976). Characterization of a benzoate permease mutant of Pseudomonas putida. Archives of Microbiology 110, 37-42.

Weill-Thevenet, N. J., Hermann, M. \& VandeCASTEELE, J.-P. (1979). Lysine transport systems in Pseudomonas in relation to their physiological function. Journal of General Microbiology 11, 263-269.

Wheelis, M. L. \& ORNSTON, L. N. (1972). Genetic control of enzyme induction in the $\beta$-ketoadipate pathway of Pseudomonas putida: deletion mapping of cat mutations. Journal of Bacteriology 109, $790-795$. 